\title{
Absorption spectrometric macronutrients review of soil health during taro crop production
}

\section{Sofina Nisha \& Surendra Prasad}

To cite this article: Sofina Nisha \& Surendra Prasad (2019): Absorption spectrometric macronutrients review of soil health during taro crop production, Applied Spectroscopy Reviews, DOI: $10.1080 / 05704928.2019 .1640719$

To link to this article: https://doi.org/10.1080/05704928.2019.1640719

\section{Published online: 25 Jul 2019.}

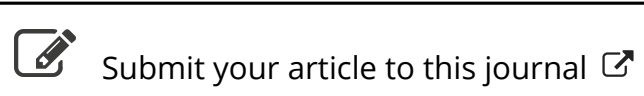

Џlll Article views: 27

Q View related articles $\asymp$

View Crossmark data $\asymp$ 


\title{
Absorption spectrometric macronutrients review of soil health during taro crop production
}

\author{
Sofina Nisha and Surendra Prasad \\ School of Biological and Chemical Sciences, Faculty of Science, Technology and Environment, The \\ University of the South Pacific, Suva, Fiji
}

\begin{abstract}
The purpose of this study was absorption spectrometric assessment the soil health of the soil from the taro growing areas of Taveuni, Fiji. The soil samples were collected in four cycles during taro cultivation period. The soil samples were analyzed for macronutrients $(\mathrm{Ca}$, $\mathrm{Mg}, \mathrm{K}, \mathrm{P}$ and $\mathrm{NO}_{3}^{-}-\mathrm{N}$ ), soil organic matter (SOM) and soil $\mathrm{pH}$. In general, the soil pH at all sites showed lower than the ideal pH (5.6-6.6) for taro planting throughout the cropping cycle. The results showed the significant loss in SOM from taro planting $(15.41 \%)$ till harvesting (5.63\%). Pronounced decrease in levels $\mathrm{NO}_{3}^{-}-\mathrm{N}$ (18.29 to $\left.13.86 \mathrm{mg} \mathrm{kg}^{-1}\right), \quad \mathrm{P} \quad\left(45.97\right.$ to $\left.25.71 \mathrm{mg} \mathrm{kg}^{-1}\right), \quad \mathrm{K} \quad(77.90$ to $\left.22.96 \mathrm{mg} \mathrm{kg}^{-1}\right)$, Ca $\left(62.20\right.$ to $27.59 \mathrm{mg} \mathrm{kg}^{-1}$ ) and $\mathrm{Mg}$ (316.10 to $121.48 \mathrm{mg} \mathrm{kg}^{-1}$ ) were recorded from planting till harvesting for different sites. There was significant reduction in the soil macronutrients and SOM in all the four study sites and some sites showed below critical level and critical to medium levels of these nutrients in the soil at the end of the harvesting period of taro. The statistical analysis of the soil test data confirmed the declining trend of the soil health on the island of Taveuni, Fiji.
\end{abstract}

\section{KEYWORDS}

Atomic absorption spectrometry; taro; soil macronutrients analysis; soil organic matter; soil fertility

\section{Introduction}

Use of absorbance techniques to identify or measure for qualitative or quantitative analysis of chemical species are as old as the first alchemists. Today absorbance measurement, involving atomic absorption spectrometry (AAS) and UV-visible spectrophotometry, remains the most widely used spectroscopic technique as a quantitative tool to measure the concentration of various chemical species foods, soils, sediments, liquids and gases due to inexpensive, their simplicity, accuracy, and ease of use (1-3). These spectrometric techniques have been applied in macronutrients assessment of soil health during taro crop production in the present report.

Taro is a crop commonly cultivated in the tropics, especially in the Pacific basin, where the leaves are consumed as vegetable and corms as staple (4). Taro is a staple food for people in developing countries including those in the South Pacific region (5, 6). Taveuni, which is third largest island in Fiji is well-known for producing the largest

CONTACT Surendra Prasad $\otimes$ prasad_su@usp.ac.fj $\mathrm{B}$ School of Biological and Chemical Sciences, Faculty of Science, Technology and Environment, The University of the South Pacific, Private Mail Bag, Suva, Fiji.

Color versions of one or more of the figures in the article can be found online at www.tandfonline.com/laps.

(C) 2019 Taylor \& Francis Group, LLC 
quantity of grade one taro and supplies approximately $70-80 \%$ of taro production in the country and exports bringing in millions of dollars as revenue. However, in some of the taro producing areas on Taveuni, there have been visible impacts of deteriorating soil health causing unsustainable taro production (7). The importance of fertile soil in maintaining high crop yield is well documented (8-11). Our study has also shown that the taro production in Taveuni, has deteriorated over time due to continuous plantation and indiscriminate and imbalanced fertilizer use (7).

It has been well accepted that the soil degradation is a serious issue and a global threat impacting almost all countries in the world. Soil degradation processes have dramatically increased in their extent and intensity over the last decades (12). Nevertheless, soil degradation continues $(13,14)$. Rural or urban farming provide healthy food and promote environmental, social, cultural and educational benefits (15). Therefore, the soil health and contamination legacy have become issues of increasing ecological, public health and food security concern (16). Thus, soil health programs and projects have been designed to influence farmers' management behaviors, usually to produce better outcomes for production, conservation and sustainability (17). Soil being a complex system, there has been regular monitoring of the soil health using as range of analytical techniques to gain a deeper understanding of the soil health (18).

Potassium $(\mathrm{K})$ is the most important and essential macronutrient that limits plant productivity after nitrogen $(\mathrm{N})$ and phosphorus $(\mathrm{P})$. Similarly, $\mathrm{N}$ and $\mathrm{P}$ are the main limiting factor for most field crops and essential for the food production (4) but not treated sustainably in most cropping system round the globe (19). The available and $\mathrm{N}$ mineralization potential of soils is an indicator of soil fertility while soil $\mathrm{P}$ is common plant growth-limiting macronutrient in the soil for sustainable agricultural production (20). The soil macronutrients, calcium (Ca) and magnesium $(\mathrm{Mg})$, are vital for the formation of cell-walls and new tissues, root and leaf development as well as for the photosynthesis process, phosphate metabolism and plant respiration. The deficiency of $\mathrm{Ca}$ and $\mathrm{Mg}$ occurs in soils that are intensively cultivated. In same way, $\mathrm{P}$ balances the cropping systems but when more $\mathrm{P}$ is removed with the products than recycled via external inputs (21), it threatens the long-term sustainability of farming systems $(19,21)$. While soil organic matter (SOM) and soil macronutrients are crucial elements of soil-plant ecosystems (22), the soil pH diagnoses soil nutrient deficiency or toxicity problem (23, 24). In other words, the management of soil nutrients is essential for sustainable agricultural production (25). Therefore, a critical part of any agricultural site is to analyze them since their presence or absence distinctly influences the soil fertility $(26,27)$. Because of the crucial role of agriculture in rural economy and increasingly serious issue of soil degradation in Taveuni, Fiji, the objective this study was absorption spectrometric assessment of the soil $\mathrm{pH}$ and the soil chemicals imbalance ( $\mathrm{Ca}, \mathrm{Mg}, \mathrm{K}, \mathrm{P}, \mathrm{NO}_{3}{ }^{-} \mathrm{N}$ and SOM) during taro cultivation and their comparison with rarely available literature data.

\section{Nutrient requirements and food value of taro}

Generally, taro has medium to high requirements for nitrogen (N), medium to low requirements for $\mathrm{P}_{2} \mathrm{O}_{5}$ and medium requirements for $\mathrm{K}_{2} \mathrm{O}$ (28). The most limiting 
Table 1. Food values of taro $(100 \mathrm{~g})$ as per Pacific Food composition table (29).

\begin{tabular}{lccc}
\hline Parameters measured (unit) & Taro corm (Raw) & Taro leaves (Raw) & Taro stalk (Raw) \\
\hline $\mathrm{H}_{2} \mathrm{O}(\mathrm{g})$ & 75 & 83 & 95 \\
Energy $(\mathrm{kJ})$ & 407 & 207 & 66 \\
Protein $(\mathrm{g})$ & 2.2 & 5.8 & 0.7 \\
Total fat $(\mathrm{g})$ & 0.4 & 1.3 & 0.3 \\
$\mathrm{CHO}(\mathrm{g})$ & 20.9 & 0.9 & 1.6 \\
$\mathrm{TDF}(\mathrm{g})$ & 1.3 & 5.7 & 2.1 \\
$\mathrm{Na}(\mathrm{mg})$ & 28 & 5 & 12 \\
$\mathrm{Mg}(\mathrm{mg})$ & 54 & 47 & 28 \\
$\mathrm{~K}(\mathrm{mg})$ & 328 & 748 & 393 \\
$\mathrm{Ca}(\mathrm{mg})$ & 34 & 276 & 46 \\
$\mathrm{Fe}(\mathrm{mg})$ & 1.2 & 2.8 & 1.2 \\
Zn $(\mathrm{mg})$ & 0.4 & 0.6 & 0.3 \\
$\beta$-carotene $(\mu \mathrm{g})$ & 26 & 6090 & 201 \\
Total Vitamin A $(\mathrm{mg})$ & 2 & 508 & 17 \\
Vitamin C $(\mathrm{mg})$ & 8 & 81 & 4 \\
Vitamin E $(\mathrm{mg})$ & 2 & 2.3 & 0.1 \\
\hline
\end{tabular}

mineral nutrient for taro growth is mostly $\mathrm{N}$. In an experiment carried out by Osorio et al. (4) to find out the effect of different $\mathrm{N}$ levels and $\mathrm{NO}_{3}^{-}: \mathrm{NH}_{4}^{+}$ratios on the growth of taro, it was found that in a total $\mathrm{N}$ level of $3 \mathrm{mM}$, taro plants best grew when the predominant $\mathrm{N}$ form in the nutrient solution was $\mathrm{NO}_{3}^{-}$. Moreover, it was found that very high levels of $\mathrm{N}$ in the form of $\mathrm{NH}_{4}{ }^{+}$becomes toxic to plants and leads to the decrease in plant growth. $\mathrm{NH}_{4}{ }^{+}$toxicity was also found to cause a decrease in $\mathrm{pH}$ levels (4).

In taro, the corm and the cormel are the main parts with nutritional value. However, the young leaves and petioles, which are also occasionally used for food, contain approximately $23 \%$ protein on a dry weight basis. Taro in general is rich in $\mathrm{Ca}, \mathrm{P}, \mathrm{Fe}$, vitamin C, thiamin, riboflavin and niacin (6). The data reported on the food value of taro in the Pacific food composition table are presented in Table 1 (29).

\section{Materials and methods}

\section{Research location and soil sampling}

The study was conducted in four sites across Taveuni island of Fiji: Matei, Mua, Vione and Delaivuna villages (Figure 1). Each site consisted of an area of $960 \mathrm{~m}^{2}$ with each plot size of $1 \mathrm{~m} \times 1 \mathrm{~m}$ area. The mucuna bean (Mucuna pruriens; a legume crop) was planted on the sample fields at each site and mulched into the soil after six months. All fields were planted with taro after the mulching process. Taro crop was harvested after six months of growing. From each of the selected sites, soil samples were collected at four different periods during the mucuna-taro cropping cycles as: (1) before planting of mucuna beans, (2) after mulching mucuna beans i.e. before planting of taro, (3) after three months of planting of taro crop and (4) after another three months i.e. at the harvesting of taro crop.

Three random soil samples were obtained from each plot of the four study sites during each of the four stages of the mucuna-taro cropping cycle. From three random soil samples, a composite soil sample was formed for each plot/stage of sampling and used for soil chemical analysis. The soil samples were collected at a depth of $30 \mathrm{~cm}$; ideal 


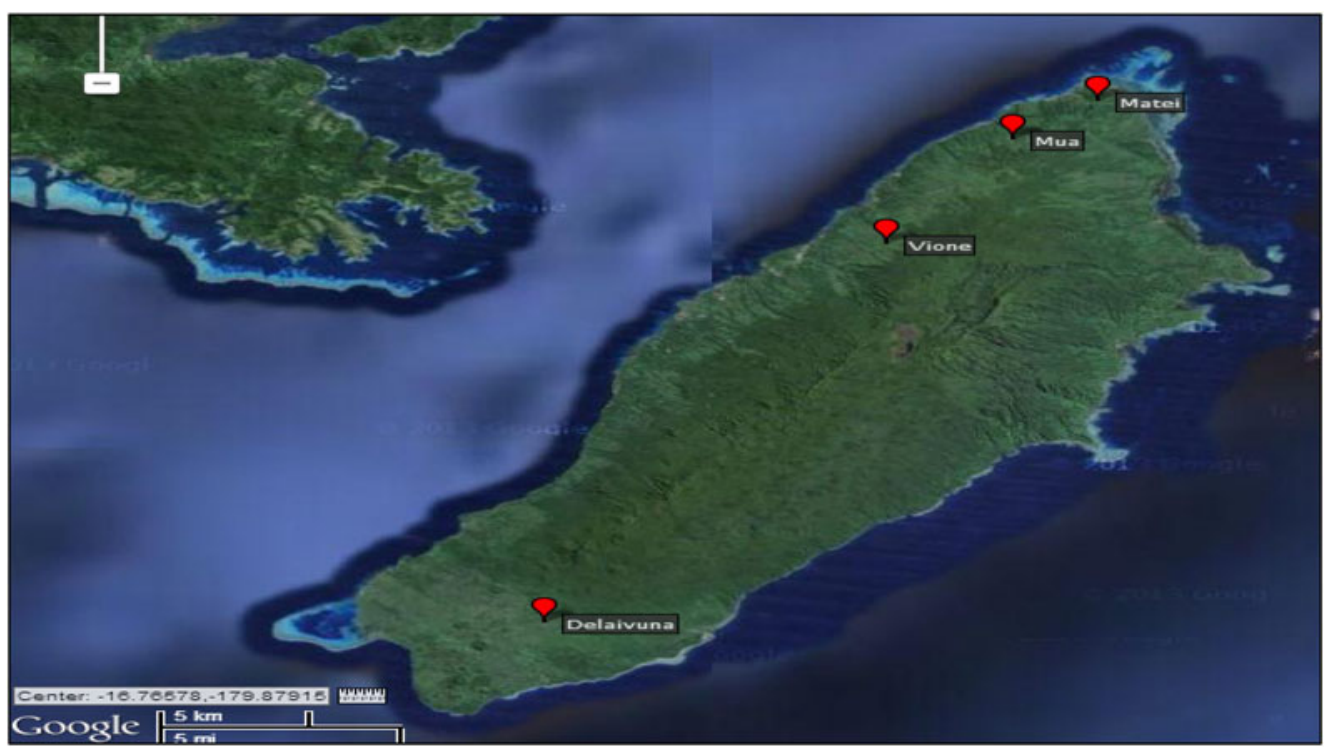

Figure 1. Distribution of the four sites across Taveuni, Fiji.

(Source: http://www.gpsvisualizer.com).

depth for the growth of most plant roots and nutrients are mixed into the soil to about that depth as well as during tillage (22). The soil samples were dried, crushed and screened through a stainless steel 10 -mesh $(2 \mathrm{~mm})$ sieve to remove unwanted debris, and then stored in zip-lock plastic bags till analysis was carried out. The soil quality of the study sites was therefore, examined for four different periods.

\section{Instrumentation}

A Lambda 25 (Perkin Elmer) UV-visible spectrophotometer with $1 \mathrm{~cm}$ matched quartz cells was used for the quantification of phosphorous (P). The QuickCkem FIA +8000 series (Lachat Instrument) flow injection analyzer (FIA) was used for the determination of nitrate $\left(\mathrm{NO}_{3}^{-}\right)$. An atomic absorption spectrophotometer (AAS) 3110 (Perkin Elmer) was used for the absorbance measurement to determine macronutrients in the soil extracts. A Hanna Instruments model $209 \mathrm{pH}$ meter was used for measuring the soil $\mathrm{pH}$ as well as setting $\mathrm{pH}$ of buffer solutions. A $360^{\circ}$ ATR model mechanical shaker was used in the experiment for extraction of macronutrients from the sample.

\section{Chemical analysis of soil}

The soil $\mathrm{pH}$ was determined using $0.01 \mathrm{M} \mathrm{CaCl}_{2}$ in a $1: 2.5$ soil to $\mathrm{CaCl}_{2}$ ratio using a pre-calibrated $\mathrm{pH}$ meter. The SOM was determined using the Walkley method (30). For soil phosphorous analysis, the nutrient was first extracted from the soil samples by shaking $1 \mathrm{~g}$ of air-dried, sieved soil sample $(<2 \mathrm{~mm})$ with $10 \mathrm{~mL}$ of $0.025 \mathrm{M} \mathrm{HCl}$ and $0.03 \mathrm{M} \mathrm{NH}_{4} \mathrm{~F}$, known as Bray-1 extracting solution, for $5 \mathrm{~min}$. The suspension was centrifuged for $10 \mathrm{~min}$ at $2000 \mathrm{rpm}$ and filtered. The filtered extract was then analyzed for 


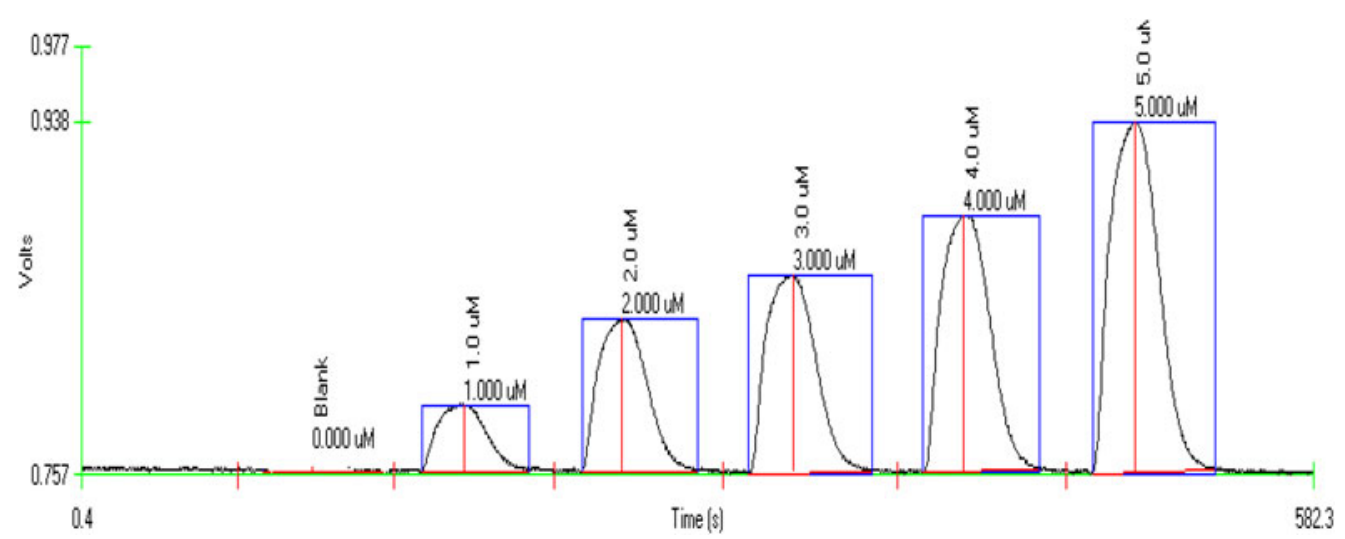

Figure 2. FIA peaks profiles for the calibration standards.

available phosphorous (P) using a UV-visible spectrophotometer by measuring absorbance at $660 \mathrm{~nm}(24,31)$.

The soil nitrate nitrogen $\left(\mathrm{NO}_{3}^{-}-\mathrm{N}\right)$ was determined by shaking $5 \mathrm{~g}$ of air-dried, sieved $(<2 \mathrm{~mm})$ soil sample in $25 \mathrm{~mL}$ of $2 \mathrm{M} \mathrm{KCl}$ extracting solution for $30 \mathrm{~min}$. The suspension was centrifuged for $10 \mathrm{~min}$ at $2000 \mathrm{rpm}$ and filtered. The filtered soil extracts were analyzed for $\mathrm{NO}_{3}^{-}-\mathrm{N}$ using FIA instrument at $520 \mathrm{~nm}$ using cadmium reduction method $(32,33)$ where $\mathrm{NO}_{3}^{-}$was reduced to $\mathrm{NO}_{2}^{-}$via a copperised cadmium $(\mathrm{Cd} / \mathrm{Cu})$ reduction column, diazotized with sulfanilamide and coupled to $\mathrm{N}$-(1-napthyl)-ethylenediamine dihydrochloride to form an azo chromophore (red-purple color). The concentration of nitrate was determined by measuring the peak area, of the dye formed, at $520 \mathrm{~nm}$ using the colorimetric detector (33). Where required, the soil extracts were diluted using the extracting solvent so that peak area could be read within the linear range of the calibration standards.

The $\mathrm{NO}_{3}^{-}$standard stock solution $1000 \mathrm{mg} / \mathrm{L}$ was prepared using $\mathrm{KNO}_{3}$. The working standards of $\mathrm{NO}_{3}^{-}(0-5 \mu \mathrm{M})$ were prepared fresh daily using $2 \mathrm{M} \mathrm{KCl}$ extracting solvent. Figure 2 shows a typical FIA peaks profiles for the calibration standards of $0-5 \mu \mathrm{M}$ $\mathrm{NO}_{3}^{-}-\mathrm{N}$ obtained through the FIA under optimum conditions at $25^{\circ} \mathrm{C}$. The $\mathrm{NO}_{3}^{-}-\mathrm{N}$ peaks obtained were clear without any interference from the organic matter in the soil matrices. The calibration graph was obtained for each run by injecting six different concentrations (triplicate) of $\mathrm{NO}_{3}^{-}-\mathrm{N}$ and plotting peak area (volts.sec) against concentration $(\mu \mathrm{M})$. A representative calibration curve of the measured peak areas versus $\mathrm{NO}_{3}^{-}$ concentrations $(\mu \mathrm{M})$ is shown in Figure 3.

The soil exchangeable bases; calcium $(\mathrm{Ca})$, magnesium $(\mathrm{Mg})$ and potassium $(\mathrm{K})$ were determined by shaking $2.5 \mathrm{~g}$ of air-dried, sieved $(<2 \mathrm{~mm})$ soil sample in $25 \mathrm{~mL}$ of $1 \mathrm{M}$ ammonium acetate $\left(\mathrm{NH}_{4} \mathrm{OAc}\right)$ extracting solution of $\mathrm{pH} 7$ for $15 \mathrm{~min}$. The suspension was centrifuged for $10 \mathrm{~min}$ at $2000 \mathrm{rpm}$ and filtered. The extract was then analyzed for $\mathrm{Ca}, \mathrm{Mg}$ and $\mathrm{K}$ using AAS (24).

\section{Quality control and statistical analysis}

A number of quality control measures were undertaken to ensure reliability of the methodology. The calibration check standards were used to ensure that the instruments were working properly. Standard and method blanks were analyzed to monitor the 


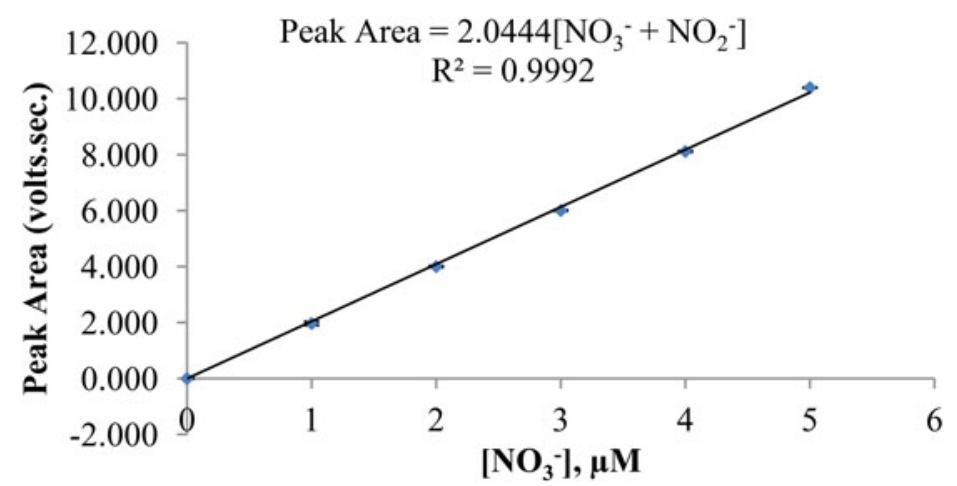

Figure 3. Calibration curve of the measured peak areas (volts.sec.) versus $\mathrm{NO}_{3}^{-}-\mathrm{N}$ concentrations $(\mu \mathrm{M})$.

purity of the reagent, deionized water and the cleanliness of glassware and equipment. The samples were analyzed in triplicates, together with duplicate extraction and repeated analysis of selected samples to confirm reproducibility and precision. Sample spiking was also performed to detect interferences present in the sample. The results on SOM and macronutrients determination were analyzed statistically using IBM SPSS Statistics 21 statistical package and Microsoft Office Excel. Descriptive statistics such as mean and standard deviation were reported.

\section{Results and discussions}

\section{Soil $\mathrm{pH}$ levels during the cropping cycle}

The $\mathrm{pH}$ of all the soil samples was determined during different stages of crop cycle (Table 2). There were no significant changes $(\rho>0.05)$ in the soil $\mathrm{pH}$ from the period before mucuna treatment till the time of taro planting for three sites (Matei, Mua and Vione). Delaivuna site however, showed significant decline in the soil $\mathrm{pH}$ for the same period $(\rho<0.05)$. From the time of taro planting till three months into planting, no significant difference was observed in the soil $\mathrm{pH}$ in the trial sites $(\rho>0.05)$. On the other hand, a significant difference existed in the $\mathrm{pH}$ levels for Mua and Deliavuna sites from three months into planting till harvest $(\rho<0.05)$. For Mua site there was an increase in the soil $\mathrm{pH}$ while Delaivuna site showed reduction in soil $\mathrm{pH}$. In general, from the time of taro planting till the time of harvest only Delaivuna site showed significant decline in soil $\mathrm{pH}$ levels $(\rho<0.05)$. However, all sites showed lower than the ideal soil pH (5.6-6.6; Koronivia Research Station, Fiji) for taro planting at the time of harvest as well as throughout the cropping cycle of taro (Table 2). The comparison of the present soil $\mathrm{pH}$ levels with the literature value available as mean topsoil $\mathrm{pH} 5.33$ of taro-exporting farms in Samoa (34) is also shown in Table 2 which is quite comparable to the present study but lower than the ideal soil pH range 5.6-6.6 reported by Koronivia Research Station, Fiji.

\section{Soil organic matter during the cropping cycle}

Soil organic carbon is important to soil nutrient status in agroecosystems and depends on types and amounts of organic matter inputs (35). The results of the SOM 
Table 2. Changes in the soil pH at different stages of the taro crop cycle at studied sites.

\begin{tabular}{lccccc}
\hline & \multicolumn{5}{c}{ Soil $\mathrm{pH}$ at studied sites } \\
\cline { 2 - 6 } Soil sampling time & Matei & Mua & Vione & Delaivuna & Samoa \\
\hline Cycle 1 & $5.41 \pm 0.07$ & $4.42 \pm 0.02$ & $4.71 \pm 0.04$ & $5.54 \pm 0.11$ & Mean topsoil pH of \\
Cycle 2 & $5.18 \pm 0.18$ & $4.34 \pm 0.28$ & $4.70 \pm 0.22$ & $5.11 \pm 0.19^{*}$ & taro-exporting \\
Cycle 3 & $5.02 \pm 0.20$ & $4.21 \pm 0.11$ & $4.66 \pm 0.10$ & $5.12 \pm 0.19$ & farms in Samoa \\
Cycle 4 & $4.99 \pm 0.04$ & $4.31 \pm 0.02^{*}$ & $4.58 \pm 0.14$ & $4.93 \pm 0.06^{*}$ & $=5.53(34)$ \\
\hline
\end{tabular}

${ }^{*}$ Significant at $\rho<0.05$.

\pm Shows standard deviation.

Table 3. Changes in the soil organic matter (SOM) at different stages of the taro crop cycle at studied sites.

\begin{tabular}{lccccc}
\hline & \multicolumn{3}{c}{ SOM content (\%) at studied sites } & Organic carbon \\
Soil sampling time & Matei & Mua & Vione & Delaivuna & Samoa \\
\hline \cline { 2 - 5 } Cycle 1 & $4.66 \pm 0.03$ & $7.32 \pm 0.01$ & $9.26 \pm 0.06$ & $10.55 \pm 0.10$ & Mean topsoil OC of \\
Cycle 2 & $5.92 \pm 0.54$ & $8.19 \pm 0.46$ & $11.00 \pm 0.62$ & $15.41 \pm 0.33$ & taro-exporting \\
Cycle 3 & $5.51 \pm 0.21$ & $7.06 \pm 0.27$ & $9.28 \pm 0.19$ & $8.11 \pm 0.64$ & farms in Samoa \\
Cycle 4 & $4.97 \pm 0.14$ & $6.27 \pm 0.33$ & $8.04 \pm 0.58$ & $5.63 \pm 0.57$ & $=11.3(34)$ \\
\hline
\end{tabular}

\pm Shows standard deviation.

determined are presented in Table 3. There was a significant increase in the SOM content $(\rho<0.05)$ during the period from mucuna treatment till the time of taro planting for all the four trial sites. The treatments, in which crop biomass i.e. mucuna were incorporated, contributed more to SOM sequestration (35). However, there was a significant decrease in SOM levels from the time of taro planting till three months of planting and from three months into planting till harvest for all the trial sites. In general, for all trial sites there was a significant decline $(\rho<0.05)$ in SOM contents from the time of taro planting till the time of harvest.

Delaivuna site showed the highest level of mean SOM content $(10.55 \pm 0.10 \%)$ in the soil while Matei site showed the lowest SOM content $(4.66 \pm 0.03 \%)$ before mucuna bean was planted on the sites. All the sites showed an improvement in the SOM levels after six months of mucuna bean treatment i.e. after mulching mucuna bean on the plots with Delaivuna site showing quite substantial increment. Delaivuna site also showed the highest loss of SOM from the time of taro planting till three months into planting and from three months into planting till harvest (Table 3). While legumes such as mucuna bean have the ability to add organic matter, etc., and improve soil quality $(36,37)$, the considerable increase in SOM content in Delaivuna site after mucuna treatment could probably be due to the effect of lime application and chemical weed control. The lime was applied to the trial sites by the 'ACIAR soil health team' during the time of mucuna bean planting and weedicides were sprayed during the mucuna treatment period. It has been reported that liming increases SOM through increased degradation of crop residues from previous harvests and dead leaves and weeds $(38,39)$. Moreover, the soil texture in Delaivuna site was mostly heavy, clay soil and the area was surrounded by rain trees, which provided a cool environment and SOM is known to accumulate under cool and poorly-drained soil conditions. However, all sites had low levels of SOM at the time of harvest of taro except for Vione site, which had medium levels of SOM as $8.04 \pm 0.58 \%$ (40). The comparison of SOM with the literature value available 
Table 4. Changes in the soil $\mathrm{NO}_{3}^{-}-\mathrm{N}$ and $\mathrm{P}$ levels at different stages of the taro crop cycle at studied sites and their comparison with the literature reported data $(34,42)$.

\begin{tabular}{|c|c|c|c|c|c|c|c|}
\hline \multirow{2}{*}{$\begin{array}{l}\text { Soil } \\
\text { sampling time }\end{array}$} & Matei & Mua & Vione & Delaivuna & Samoa & Nagpur*1 & Nagpur*2 \\
\hline & \multicolumn{4}{|c|}{$\mathrm{NO}_{3}^{-}-\mathrm{N}\left(\mathrm{mgkg}^{-1}\right)$ at studied sites } & \multicolumn{3}{|c|}{ Total $\mathrm{N}\left(\mathrm{mgkg}^{-1}\right)$ at studied sites } \\
\hline Cycle 2 & $18.29 \pm 2.80$ & $16.91 \pm 1.59$ & $25.71 \pm 1.98$ & $16.84 \pm 2.20$ & Mean topsoil & Mean soil $\mathrm{N}$ & Mean soil $\mathrm{N}$ \\
\hline Cycle 3 & $16.26 \pm 1.09^{*}$ & $15.43 \pm 1.16^{*}$ & $22.23 \pm 1.64$ & $16.47 \pm 2.07^{*}$ & $\mathrm{~N}$ of taro- & concentration & concentration \\
\hline \multirow[t]{2}{*}{ Cycle 4} & $13.86 \pm 0.95$ & $12.82 \pm 0.42$ & $20.37 \pm 1.33$ & $14.36 \pm 2.84^{*}$ & $\begin{array}{l}\text { exporting } \\
\text { farms in } \\
\text { Samoa }= \\
10,200(34)\end{array}$ & $\begin{array}{l}\text { between low } \\
\text { yielding } \\
\text { orchards = } \\
101.23(42)\end{array}$ & $\begin{array}{l}\text { between high } \\
\text { yielding } \\
\text { orchards = } \\
124.75(42)\end{array}$ \\
\hline & \multicolumn{4}{|c|}{$\mathrm{P}\left(\mathrm{mgkg}^{-1}\right)$ at studied sites } & \multicolumn{3}{|c|}{ Total $P\left(\mathrm{mgkg}^{-1}\right)$ at studied sites } \\
\hline Cycle 1 & $33.20 \pm 0.19$ & $24.10 \pm 0.36$ & $25.39 \pm 0.53$ & $45.97 \pm 0.42$ & Mean topsoil & Pean soil P & Mean soil P \\
\hline Cycle 2 & $26.29 \pm 1.40$ & $19.48 \pm 1.54$ & $24.79 \pm 1.66^{*}$ & $39.40 \pm 2.84$ & of taro- & concentration & concentration \\
\hline Cycle 3 & $19.58 \pm 2.33$ & $20.60 \pm 1.40^{*}$ & $18.26 \pm 1.01$ & $26.97 \pm 2.62$ & exporting & between low & between high \\
\hline Cycle 4 & $15.83 \pm 1.40$ & $14.69 \pm 0.64$ & $13.02 \pm 1.60$ & $25.71 \pm 3.12^{*}$ & $\begin{array}{l}\text { farms in } \\
\text { Samoa = } \\
10.10(34)\end{array}$ & $\begin{array}{l}\text { yielding } \\
\text { orchards }= \\
9.11(42)\end{array}$ & $\begin{array}{l}\text { yielding } \\
\text { orchards }= \\
11.23(42)\end{array}$ \\
\hline
\end{tabular}

${ }^{*}$ Not significant at $\rho>0.05$.

${ }^{* 1}$ Mean soil nutrient concentration between low yielding orchards.

${ }^{*}$ Mean soil nutrient concentration between high yielding orchards.

${ }^{ \pm}$Shows standard deviation.

as the mean topsoil organic carbon (OC; 11.3\%) of taro-exporting farms in Samoa is comparable to SOM found at few sites but in general higher than the present study (Table 3).

\section{Soil $\mathrm{NO}_{3}^{-}-\mathrm{N}$ analysis during the cropping cycle}

The $\mathrm{NO}_{3}^{-}-\mathrm{N}$ contents in different soil samples determined have been presented in Table 4. The results of nitrate analysis showed a decline in $\mathrm{NO}_{3}^{-}-\mathrm{N}$ in the soils from the time of taro planting till three months into planting for all four sites (Matei, Mua, Vione and Delaivuna). However, while the decline in $\mathrm{NO}_{3}^{-}-\mathrm{N}$ was significant for Vione site $(\rho<0.05)$, it was not significant for Matei, Mua and Delaivuna sites $(\rho>0.05)$. Similarly, a decline in the $\mathrm{NO}_{3}^{-}-\mathrm{N}$ levels was noted in all four sites from three months into planting till harvest. For Matei, Mua and Vione sites, this decline was significant $(\rho<0.05)$ whereas for Delaivuna site, it was not significant. In general, there has been a significant decrease in $\mathrm{NO}_{3}^{-}-\mathrm{N}$ levels from the time of taro planting till the time of harvest for all four sites. Vione site showed the highest level of mean $\mathrm{NO}_{3}^{-}-\mathrm{N}$ content $\left(20.37 \pm 1.33 \mathrm{mg} \mathrm{kg}^{-1}\right)$ in the soil at the time of harvest while Mua site showed the lowest level $\left(12.82 \pm 0.42 \mathrm{mg} \mathrm{kg}^{-1}\right)$. The ideal $\mathrm{NO}_{3}^{-}-\mathrm{N}$ level in the soil for taro cultivation is $25-30 \mathrm{mg} \mathrm{kg}^{-1}$ (41). Thus, all sites had low levels of $\mathrm{NO}_{3}^{-}-\mathrm{N}$ at the time of harvest of taro indicating $\mathrm{N}$ deficiency. The $\mathrm{NO}_{3}^{-}-\mathrm{N}$, which is the principal source of $\mathrm{N}$ for plants, is relatively unstable in the soil unlike other soil nutrients such as $\mathrm{P}$ or $\mathrm{K}$, and thus is easily lost from the soil through various pathways. The comparison of the present $\mathrm{NO}_{3}^{-}$$\mathrm{N}$ contents in different soil samples with the literature value available as mean topsoil nitrogen $(\mathrm{N})$ of taro-exporting farms in Samoa as 10,200 (34) and the mean soil $\mathrm{N}$ concentration between low-yielding orchards and between high-yielding orchards in Nagpur (India) as 101.23 and $124.75 \mathrm{mg} \mathrm{kg}^{-1}$, respectively (42) are also shown in 
Table 4. The present study shows lower contents in comparison to the literature reported values.

\section{Soil $P$ analysis during the cropping cycle}

The $\mathrm{P}$ contents in the soils for the four sites shown in Table 4 indicated a decline at each of the four stages. However, while the decline in $\mathrm{P}$ content for Matei, Mua and Delaivuna sites was significant, the decline of $\mathrm{P}$ content at Vione site was not significant $(\rho>0.05)$ for the period before mucuna beans were planted till the period when taro was planted i.e. after mucuna treatment for six months. From the time of taro planting till three months into planting, the reduction in $\mathrm{P}$ levels for Mua site was not significant. Conversely, for the same period of time, the decline in Matei, Vione and Delaivuna sites was significant $(\rho<0.05)$. Moreover, from three months into planting of taro till harvest, the decline in $\mathrm{P}$ levels was significant for Matei, Mua and Vione sites while it was not significant for Delaivuna site.

In general, the $\mathrm{P}$ levels in the soil had a significant decline from the time of taro planting till harvest for all sites. Delaivuna site showed the highest level of mean $\mathrm{P}$ content $\left(25.71 \pm 3.12 \mathrm{mg} \mathrm{kg}^{-1}\right)$ in the soil at the time of harvest while the lowest level was recorded for Vione site $\left(13.03 \pm 1.60 \mathrm{mg} \mathrm{kg}^{-1}\right)$. The tropical soils show $\mathrm{P}$ deficiency due to the soil mineralogical composition. Hence, the low available $\mathrm{P}$ in the study sites could be associated with the formation of relatively insoluble phosphates (43). The comparison of the present $\mathrm{P}$ contents in different soil samples with the literature values available as mean topsoil $\mathrm{P}$ of taro-exporting farms in Samoa as $10.1 \mathrm{mg} \mathrm{kg}^{-1}$ (34) and the mean soil $\mathrm{P}$ concentration between low-yielding orchards and between high-yielding orchards in Nagpur (India) as 9.11 and $11.23 \mathrm{mg} \mathrm{kg}^{-1}$, respectively (42) are also shown in Table 4. The present data show slightly higher values in comparison to the literature reported soil $\mathrm{P}$ contents (Table 4).

\section{Soil $K$ analysis during the cropping cycle}

The potassium contents of the soil samples are shown in Table 5. There was a significant decrease in $\mathrm{K}$ contents at all sites prior to mucuna treatment till the time of taro planting $(\rho<0.05)$. Similarly, Vione and Delaivuna sites showed significant decline in the $\mathrm{K}$ content in the soil from the period when taro was planted till three months into planting. However, in the Matei and Mua sites, the reduction in the $\mathrm{K}$ content in the soil in the same period was not significant. Moreover, from three months into planting till harvest, the decline in $\mathrm{K}$ levels in all the sites was significant at $95 \%$ confidence interval. Therefore, the $\mathrm{K}$ levels in the soil had a significant decline from the time of taro planting till harvest for all the four sites.

At the time of harvest, the highest level of mean $\mathrm{K}$ content in the soil was recorded for Matei site $\left(209.82 \pm 25.44 \mathrm{mg} \mathrm{kg}^{-1}\right)$ whilst the lowest level was recorded for Delaivuna site $\left(15.85 \pm 1.65 \mathrm{mg} \mathrm{kg}^{-1}\right)$. According to standard ratings, Matei was the only site which showed ideal levels of $\mathrm{K}\left(117-234 \mathrm{mg} \mathrm{kg}^{-1}\right)$ at the time of harvest (40). Mua, Vione and Delaivuna site showed below critical levels of soil $\mathrm{K}$ at the time of taro harvest $\left(<39 \mathrm{mg} \mathrm{kg}^{-1}\right)$. Before the cropping cycle of taro, Matei site showed high level of 


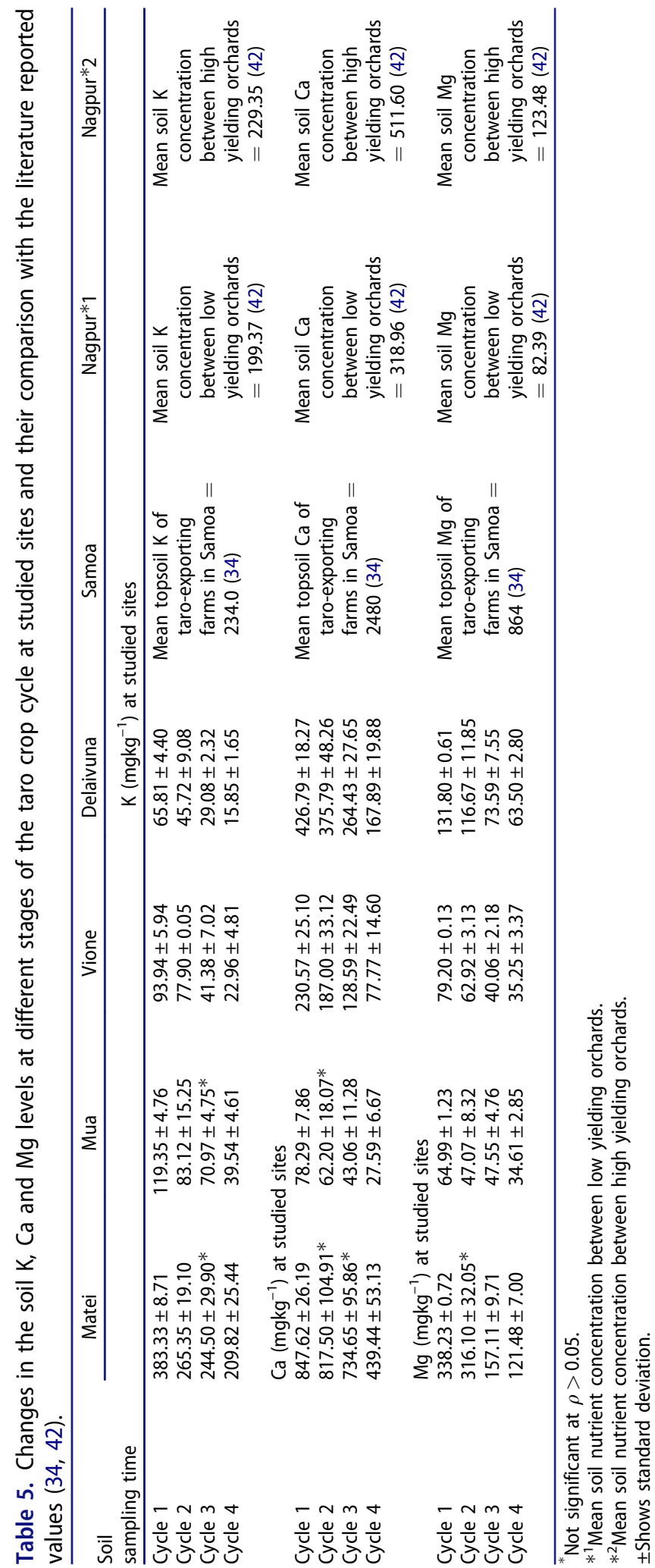


the soil $\mathrm{K}$ while Mua site showed sufficient level of the soil $\mathrm{K}$. The soil $\mathrm{K}$ is easily lost from soils of fine texture such as clay and clay loam soils because of its availability in soluble and exchangeable forms. The soils in the four study sites are of clay to clay loam nature (7); hence $\mathrm{K}$ could have been easily leached through the soil, resulting in low and declining levels of soil $\mathrm{K}$ in the sites. The $\mathrm{K}$ contents in the present study for different soil samples are comparable to the literature values as mean topsoil $\mathrm{K}$ of taroexporting farms in Samoa as $234 \mathrm{mg} \mathrm{kg}^{-1}$ (34) and the mean soil $\mathrm{K}$ concentration between low-yielding orchards and between high-yielding orchards in Nagpur, India as 197.37 and $229.35 \mathrm{mg} \mathrm{kg}^{-1}$, respectively (42) only for Matei site but much higher than in the soil samples from Mua, Vione and Delaivuna sites (Table 5).

\section{Soil $\mathrm{Ca}$ analysis during the cropping cycle}

The calcium contents in the analyzed soil samples collected at different stages of the cropping cycle are shown in Table 5. The significant differences in soil Ca were observed for all sites: Matei, Mua, Vione and Delaivuna. The results in Table 5 show a decline trend at each stage of the cropping cycle. However, while the decline in $\mathrm{Ca}$ content for the Vione and Delaivuna sites was significant, the decline for Matei and Mua sites was not significant for the period from planting of mucuna bean till the period when taro was planted i.e. six months after mucuna treatment. The decline in Ca levels in the soil from the time of taro planting till three months into planting was significant for Mua, Vione and Delaivuna sites. It was, however, not significant for Matei site. Also, from three months into planting of taro till harvest, the decline in Ca levels was significant for all the four sites. Therefore, in general, the Ca level in the soil declined from the time of taro planting till harvest for all the sites.

Matei site had the highest level of mean Ca content $\left(439.44 \pm 53.13 \mathrm{mg} \mathrm{kg}^{-1}\right)$ in the soil at the time of taro harvest while Mua site had the lowest $\left(27.59 \pm 6.67 \mathrm{mg} \mathrm{kg}^{-1}\right)$. However, all the sites (Mua, Vione and Delaivuna) except for Matei site had Ca levels below critical levels $400 \mathrm{mg} \mathrm{kg}^{-1}$ at the time of harvest of taro (40). The results in Table 5 clearly shows that Mua and Vione sites had low levels of Ca even prior to farm preparation for taro planting via mucuna treatment and indicated $\mathrm{Ca}$ deficiency throughout the cropping cycle. Acidic soils usually show evidence of Ca deficiencies which is a factor contributing to lower soil Ca level in the study sites. Similarly, as in case of K, the Ca contents in the present study for different soil samples are lower than the literature reported mean topsoil Ca of taro-exporting farms in Samoa (34) and the mean soil Ca concentration between low yielding orchards and between high yielding orchards in Nagpur, India (42) except for Matei site (Table 5). However, Ca contents at Matei site soil are lower than the mean topsoil $\mathrm{Ca}$ contents of taro-exporting farms in Samoa $2480 \mathrm{mg} \mathrm{kg}^{-1}$ as reported by Guinto et al. (34).

\section{Soil Mg analysis during the cropping cycle}

The results on the magnesium analysis in the soil samples of different stages of the cropping cycle are shown in Table 5. The decline in Mg content in the soil at Matei site 
from mucuna treatment till taro planting was not significant $(\rho>0.05)$. As shown in Table 5, for the same period, a significant decline in $\mathrm{Mg}$ levels was observed for Mua, Vione and Delaivuna sites. Similarly, the decline in $\mathrm{Mg}$ contents in the soil was found to be significant in all the four sites from the time of taro planting till three months into planting and also from three months into planting till harvest. Thus, in general, the $\mathrm{Mg}$ level in the soil has had a significant decline from the time of taro planting till harvest for all the sites. The highest level of $\mathrm{Mg}$ content in the soil at the time of taro harvest was found for Matei site $\left(121.48 \pm 7 \mathrm{mg} \mathrm{kg}^{-1}\right)$ while the lowest level was in Mua site $\left(34.61 \pm 2.85 \mathrm{mg} \mathrm{kg}^{-1}\right)$. Matei site was the only site that had sufficient levels of soil $\mathrm{Mg}\left(>121 \mathrm{mg} \mathrm{kg}^{-1}\right)$ at the time of taro harvest, while the remaining three sites (Mua, Vione and Delaivuna) had critical levels $\left(<60 \mathrm{mg} \mathrm{kg}^{-1}\right)$ of soil $\mathrm{Mg}(40)$. As in the case of soil Ca level, Mua and Vione site had low levels of $\mathrm{Mg}$ even before mucuna bean was planted for land preparation before taro planting and showed signs of $\mathrm{Mg}$ deficiency throughout the cropping cycle (Table 5). In humid areas, such as the tropics, $\mathrm{Mg}$, like $\mathrm{Ca}$, is easily leached through the soil and a contributing factor to lower $\mathrm{Mg}$ levels in the studied sites. $\mathrm{Mg}$ contents in the present study for different soil samples are lower than the mean $\mathrm{Mg}$ contents of taro-exporting farms in Samoa (34) and $\mathrm{Mg}$ concentration between low-yielding orchards and between high-yielding orchards in Nagpur, India (42) except Delaivuna sites in cycle 1 (Table 5).

\section{Conclusion}

The results obtained from absorption spectrometric assessment of the soil from the taro growing areas of Taveuni, Fiji, showed that after one cropping season of taro, soil $\mathrm{pH}, \mathrm{SOM}$ and macronutrients had generally declined significantly in most of the study sites. Thus, the continuous planting has exhausted the soils nutrient reserves, thereby causing the deterioration of soil health. If another season of taro cultivation is done on the same piece of land with no time for nutrient replenishment or with no organic and/or inorganic nutrient input, deficiencies of these essential elements in the soil will limit the growth of the plant. This will lead to decrease in the agricultural production capacity, food security and livelihoods. Thus, it is necessary to improve agricultural sustainability through the most favorable nutrients management practices to maintain soil fertility.

\section{Acknowledgment}

The authors are grateful to the Australian Center for International Agricultural Research (ACIAR) for awarding Graduate Assistantship to Ms. Sofina Nisha for her M.Sc. study at the University of the South Pacific, Suva, Fiji.

\section{Funding}

The financial support by ACIAR through the FSTE Research Committee via project thesis vote code no. 6C341-1311-a/c-00 is also acknowledged. 


\section{References}

1. Beck, J. N., and Sneddon, J. (2000) Use of atomic absorption spectrometry for the determination of metals in sediments in southwest Louisiana. Microchem. J., 66(1-3):73-114.

2. Sneddon, J., Rode, P. W., Hamilton, M. A., Pingeli, S., and Hagen, J. P. (2007) Determination of metals in seafood and fish in Southwest Louisiana. Appl. Spectrosc. Rev., 42, (1):23-42.

3. Sneddon, J., Richert, J. C., and Hardaway, C. J. (2019) Studies of metals in soil, sediments, and selected food in Southwest Louisiana. Appl. Spectrosc. Rev., 54(3):264-274.

4. Osorio, W., Shuai, X., Miyasaka, S., Wang, B., Shirey, L., and Wigmore, J. (2003) Nitrogen level and form affect taro growth and nutrition. HortScience, 38(1):36-40.

5. Goenaga, R., and Chardon, U. (1995) Growth, yield and nutrient uptake of taro grown under upland condition. J. Plant Nutr., 18(5):1037-1048.

6. Tumuhimbise, R., Talwana, I., Osiru, O., Serem, K., Ndabikunze, K., Nandi, M., and Palapala, V. (2009) Growth and development of wetland-grown taro under different plant populations and seedbed types in Uganda. Afr. Crop Sci. J., 17:49-60.

7. Nisha, S., Prasad, S., and Bhati, J. (2014) Evaluation of soil chemical nutrient management practices of taro farmers' in Taveuni, Fiji. South Pac. J. Nat. Appl. Sci., 32(2):61-68.

8. Bhat, R., Sujatha, S., and Jose, C. T. (2012) Assessing soil fertility of a laterite soil in relation to yield of arecanut (Areca catechu L.) in humid tropics of India. Geoderma, 189-190: 91-97.

9. Cox, F. R., and Barnes, J. S. (2002) Peanut, corn, and cotton critical levels for phosphorus and potassium on Goldsboro soil. Commun. Soil Sci. Plant Anal., 33(7-8):1173-1186.

10. Kravchenko, A. N., and Bullock, D. G. (2000) Correlation of corn and soybean grain yield with topography and soil properties. Agron. J., 92(1):75-83.

11. Masikati, P., Manschadi, A., Rooyen, A., and Hargreaves, J. (2014) Maiza-mucuna rotation: An alternative technology to improve water productivity in smallholder farming systems. Agric. Syst., 123:62-70.

12. Cécillon, L., Barthès, B. G., Gomez, C., Ertlen, D., Genot, V., Hedde, M., Stevens, A., and Brun, J. J. (2009) Assessment and monitoring of soil quality using near-infrared reflectance spectroscopy (NIRS). Eur. J. Soil Sci., 60(5):770-784.

13. Prager, K., and Curfs, O. (2016) Using mental models to understand soil management. Soil Use Manage. 32(1):36-44.

14. Sione, S. M. J., Marcelo Germán Wilson, M. G., Lado, M., and Antonio Paz González, A. P. (2017) Evaluation of soil degradation produced by rice crop systems in a Vertisol, using a soil quality index. Catena, 150:79-86.

15. Cheng, Z., Paltseva, A., Li, I., Morin, T., Huot, H., Egendorf, S., Su, Z., Yolanda, R., Singh, K., Lee, L., Grinshtein, M., Liu, Y., Green, K., Wai, W., Wazed, B., and Shaw, R. (2015) Trace metal contamination in New York City Garden soils. Soil Sci., 180(4/5):167-213.

16. Evans, J. M., Parker, A., Gallagher, F., and Krumins, J. A. (2015) Plant productivity, ectomycorrhizae, and metal contamination in urban brownfield soils. Soil Sci., 180(4/5): 198-206.

17. Kelly, B., Allan, C., and Wilson, B. P. (2009) Soil indicators and their use by farmers in the Billabong Catchment, southern New South Wales. Soil Res., 47(2):234-242.

18. Bezuidenhout, C. N., Antwerpen, RV., and Berry, S. D. (2012) An application of principal component analyses and correlation graphs to assess multivariate soil health properties. Soil Sci., 177(8):498-505.

19. Weissengruber, L., Möller, K., Puschenreiter, M., and Friedel, J. K. (2018) Long-term soil accumulation of potentially toxic elements and selected organic pollutants through application of recycled phosphorus fertilizers for organic farming conditions. Nutr. Cycl. Agroecosyst. 110(3):427-449.

20. Tilahun, G. (2007) Soil fertility status as influenced by different land uses in Maybar Areas of South Wello Zone, North Ethiopia. M.Sc. Thesis, The Faculty of the Department of Plant Sciences, School of Graduate Studies, Haramaya University, Ethiopia. 
21. Ohm, M., Paulsen, H. M., Moos, J. H., and Eichler-LöBermann, B. (2017) Long-term negative phosphorus budgets in organic crop rotations deplete plant-available phosphorus from soil. Agron. Sustainable Dev., 37:1-9.

22. Erfanzadeh, R., Bahrami, B., Motamedi, J., and Pétillon, J. (2014) Changes in soil organic matter driven by shifts in co-dominant plant species in a grassland. Geoderma, 213:74-78.

23. Canali, S., Bartolomeo, E., Trinchera, A., Nisini, L., Tittarelli, F., Intrigliolo, F., Roccuzzo, G., and Calabretta, M. (2009) Effect of different management strategies on soil quality of citrus orchards in Southern Italy. Soil Use Manage., 25(1):34-42.

24. Hak-Jin, K., Kenneth, A., and John, W. (2009) Soil macronutrient sensing for precision agriculture. J. Environ. Monit., 11:1810-1824.

25. Mayrink, G. O., Valente, D. S. M., Queiroz, D. M., and Pinto, F. A. C. (2018) Determination of chemical soil properties using diffuse reflectance and ion-exchange resins. Precis. Agric., 23(3):541-561. doi:10.1007/s11119-018-9597-y

26. Mbah, C., and Onweremadu, E. (2009) Effect of organic and mineral fertilizer inputs on soil and maize grain yield in an acid ultisol in Abakaliki-South Eastern Nigeria. Am. Eurasian J. Agron., 2:7-12.

27. Simon, T., Mikanova, O., and Cerhanova, D. (2013) Long-term effect of straw and farmyard manure on soil organic matter in field experiment in the Czech Republic. Arch. Agron. Soil Sci., 59:1193-1205.

28. Lamberts, M., and Olson, S. (2012) Tropical root crop production in Florida. University of Florida, USA, pp. 345-351.

29. Dignan, C., Burlingame, B., Kumar, S., and Aalbersberg, W. (2004) The Pacific Islands food composition tables. 2th ed. Food and Agriculture Organization of the United Nations, Rome, Italy: chief, Publishing management service, Information division. pp. 6-23.

30. Walkley, A. (1947) A critical examination of a rapid method for determining organic carbon in soils- Effect of variations in digestion conditions and of inorganic soil constituents. Soil Sci., 63(4):251-264.

31. Bray, R., and Kurtz, L. (1945) Determination of total organic and available forms of phosphorus in soils. Soil Sci., 59(1):39-45.

32. Dorich, R., and Nelson, D. (1984) Evaluation of manual cadmium reduction methods for determination of nitrate in potassium chloride extracts of soils. Soil Sci. Soc. Am. J., 48(1): 72-75.

33. Prasad, S., and Chetty, A. A. (2008) Nitrate-N determination in leafy vegetables: study of the effects of cooking and freezing. Food Chem., 106(2):772-780.

34. Guinto, F. D., Lauga, S., Dauara, L., Walasi, E., Autifuga, D., Perera, H., Seuoti, D., Sae, A., and Tauati, S. (2015) Soil health assessment of taro (Colocasia esculenta) farms in Samoa, Presented at 18th Philippine society of soil science and Technology (PSST) Annual meeting $\begin{array}{llll}\text { and Sceintific may } & \text { Conference, }\end{array}$ SEARSOLIN Xavier University. Cagayan de Orocity, Philippines:4-5.

35. You, M., Burger, M., Li, L., Zou, W., Li, N., Qiao, Y., and Han, X. (2014) Changes in soil organic carbon and carbon fractions under different land use and management practices after development from parent material of mollisols. Soil Sci., 179(4):205-210.

36. Amba, A., Agbo, E., Voncir, N., and Oyawoye, M. (2011) Effect of phosphorus fertilizer on some soil chemical properties and nitrogen fixation of legumes at Bauchi. Cont. J. Agric. Sci., 5:39-44.

37. Ritchie, M., and Tilman, D. (1995) Responses of legumes to herbivores and nutrients during succession on a nitrogen-poor soil. Ecology, 76(8):2648-2655.

38. Condron, L., Tiessen, H., Trasar-Cepeda, C., Moir, J., and Stewart, J. (1993) Effects of liming on organic matter decomposition and phosphorus extractability in an acid humic ranker soil from Northwest Spain. Biol. Fertil. Soils, 15(4):279-284.

39. Haynes, R., and Naidu, R. (1998) Influence of lime, fertilizer and manure applications on soil organic matter content and soil physical conditions: A review. Nutr. Cycling Agroecosyst., 51(2):123-137. 
40. Thiagalingam, K. (2000) Soil and plant sample collection, preparation and interpretation of chemical analysis: A training manual and guide. AACM International, Adelaide, Australia.

41. Heckman, J. (2002) In-season soil nitrate testing as a guide to nitrogen management for annual crops. Hortic. Technol., 12:706-710.

42. Srivastava, A. K., and Singh, S. (2008) Dris norms and their field validation in Nagpur Mandarin. J. Plant Nutr., 31(6):1091-1107.

43. Ogwang, B. (1988) The mineral status of soil, forage and cattle tissues in the middleville of Swaziland. Ex. Agric., 24(2):177-182. 